\title{
Livestock Breeders' Adaptation to Climate Variability and Change in Morocco's Arid Rangelands
}

\author{
Wadii Snaibi and Abdelhamid Mezrhab
}

\section{Contents}

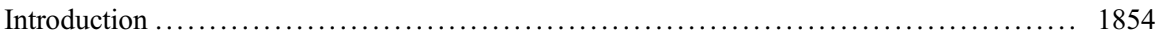

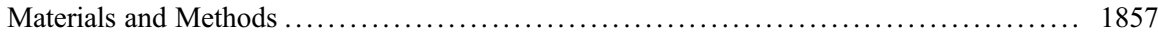

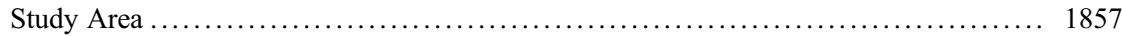

Data Collection ...................................................... 1857

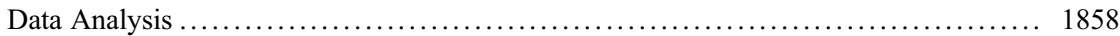

Results and Discussion .................................................. 1859

Socioeconomic Characteristics of Breeders Surveyed ........................... 1859

Analysis of Pastoralists Adaptation Practices in the HPEM ........................ 1859

Differentiation of Adaptation Measures According to Breeders' Classes ............... 1861

Factors Influencing the Adoption of Climate Change Adaptation Practices ............ 1864

Conclusion ................................................................. 1869

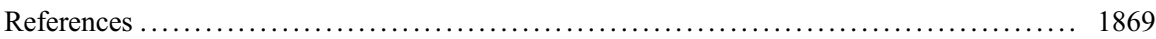

\section{Abstract}

Since the mid-1970s, the high plateaus of eastern Morocco have experienced proven trends of climate change (CC) such as a significant decrease in rainfall amounts and an increase in the droughts' frequency. Consequently, the CC threatens the sustainability of this pastoral ecosystem and negatively affects the

This chapter was previously published non-open access with exclusive rights reserved by the Publisher. It has been changed retrospectively to open access under a CC BY 4.0 license and the copyright holder is "The Author(s)". For further details, please see the license information at the end of the chapter.

\section{W. Snaibi $(\bowtie)$}

Laboratory Communication, Education, Digital Usage and Creativity, ETIGGE Research Team, Bd. Mohammed VI, University Complex, Mohammed Premier Oujda University, Oujda, Morocco

National Institute of the Agronomic Research of Morocco, CRRA of Oujda, Oujda, Morocco
A. Mezrhab
Laboratory Communication, Education, Digital Usage and Creativity, ETIGGE Research Team, Bd. Mohammed VI, University Complex, Mohammed Premier Oujda University, Oujda, Morocco 
breeding of small ruminants, the main local-level livelihood, which becomes more vulnerable due to its high dependence on climatic conditions. This chapter aims to analyze breeders' adaptation practices by taking into account their social stratification based on the size of the sheep flock in possession. Data were analyzed using descriptive statistics, Kruskal-Wallis and Mann-Whitney tests to examine the differences in the adoption' frequency of CC adaptation measures according breeders' classes and Chi-square independence test to identify the factors explaining these observed differences. The analysis of local adaptation practices reveals that they are endogenous but above all curative, aiming at a short-term logic and have a low to medium relevance compared to the specific objective of adaptation to $\mathrm{CC}$. In addition, there are significant differences in the frequency of adoption of $\mathrm{CC}$ adaptation strategies (chi-square value $=8.1112$, $p=0.017, \mathrm{df}=2$ ) within categories of breeders, in particular between small and larger breeders $(\mathrm{U}$ statistic $=58.000, p=0.008$ ). The significant factors explaining these differences are socioeconomic (age, household size, equipment, training, and membership of a basic professional organization). It is therefore recommended to target small breeders as a priority and to set up support measures (equipment, training, funding, organization of breeders).

\section{Keywords}

Climate change $\cdot$ Adaptation $\cdot$ Pastoralists $\cdot$ Arid rangelands $\cdot$ Morocco

\section{Introduction}

Currently, climate change (CC) has become obvious, due to its manifold effects on human and natural systems, affecting all countries of the world (IPCC 2014). Africa is considered one of the most vulnerable continents to climate change and extreme events (Garcia 2008). This vulnerability is principally attributed to the low level of economic development in its countries, thus generating a weak and limited adaptive capacity to deal with the negative physical, human, and socioeconomic impacts of CC (Besada and Sewankambo 2009; Bruckner 2012).

Within North African countries, Morocco is seen as the most vulnerable to climatic change and extremes, due to the combination of high exposure to climate consequences, marked climate sensitivity (high dependency on rain-fed agriculture, recurrent water stress), and a weak generic adaptive capacity (low income per capita and its unequal distribution) (Yohe et al. 2006; Schilling et al. 2012). Indeed, Morocco has already suffered the impacts of climate change, evidenced by the climate trends observed during the period from 1960 to 2005. Thus, aridity has increased from the south to the north of the country (Mokssit 2012), rainfall had seen a widespread decline (Schilling et al. 2012) of between 3\% and 30\% (Ezouine and Bouaza 2019), while the temperature has risen (Hulme et al. 2001) from 1.0 to more than $1.8{ }^{\circ} \mathrm{C}$ (Morocco 2016). In addition, the frequency, intensity and duration of droughts have increased during the last three decades (Moroccan Meteorological 
Office 2007; NIC 2009). Climate change projections for Morocco, exhibit a decrease in annual rainfall amounts of 10-20\% by 2100 (Mokssit 2012; Morocco 2016) and an increase in temperature until 2050 between $1.0^{\circ} \mathrm{C}$ to $1.2^{\circ} \mathrm{C}$ (Schilling et al. 2012) or ranging from $2{ }^{\circ} \mathrm{C}$ to $3{ }^{\circ} \mathrm{C}$ according to Paeth et al. (2009). Also, the frequency and the duration of droughts are forecasted to rise (Beniston et al. 2007; Bzioui 2012; Schilling et al. 2012). In short, negative climatic changes already observed are likely to continue in the twenty-first century, resulting in warmer and drier conditions (Schilling et al. 2012). Agriculture, the key economic sector and the main provider of jobs, is the most negatively affected by the effects of CC (Morocco 2016). Thereby, rural populations whose rain-fed agriculture is the major source of income are hardest hit because of their high vulnerability to the harmful consequences of climate change (Morocco 2011).

In this context, the study area, namely, the high plateaus of eastern Morocco (HPEM), has experienced proven climate change trends since the late 1970s, such as a substantial decrease in rainfall (Fink et al. 2010; François et al. 2016; Melhaoui et al. 2018) and an increase in temperature and frequency of droughts (Moroccan Meteorological Office 2007; François et al. 2016; Melhaoui et al. 2018). Livestock breeding on rangelands, based mostly on the sheep farming, is the main livelihood and job provider for the local population. This economic activity is vulnerable to CC due to its high dependence on climatic conditions (Bechchari et al. 2014), which are characterized by high intra- and inter-annual variability in rainfall and recurrent droughts (Mahyou et al. 2010; Bechchari et al. 2014). In fact, livestock breeding on arid rangelands is severely affected by the adverse impacts of extreme climate change events since it depends on natural resources and practiced in a fragile and marginal environment such as the pastoral ecosystem of the study area. As highlighted by Hassan (2010) drylands present an intrinsic natural vulnerability generated by a high exposure to significant water stress. Indeed, climate change and extremes in the high plateaus of eastern Morocco threatened the sustainability of pastoral livestock rearing, accentuated the precariousness of the poorest rural households and increased the flow of potential emigrants. Also, extreme climatic events (drought in particular), that have occurred in the HPEM in the past, have caused fodder and water scarcities leading to higher competition for available natural resources and to sometimes brutal pastoral conflicts (Bourbouze and El Aich 2000).

The increase in the occurrence and intensity of climate change-induced droughts and their prolongation over time exacerbated social inequalities among local breeders (Schilling et al. 2012). Indeed, at the time of drought event, small-scale livestock owners face both increased pressure on available pastoral resources and an inability to purchase higher-priced livestock feeds. Thereafter, the size of their herds decreases considerably, while large breeders, their strategy of decapitalization seems to be well under control and their ability to replenish herds is much greater (Bourbouze 2000; Bechchari et al. 2014). In fact, better-off herders are slightly less vulnerable because they are not exclusively or largely dependent on natural resources, have the financial resources to buy livestock feed, and can even take advantage of this opportunity created by the decapitalization of the poorest livestock owners (Kuhn et al. 2010; Bechchari et al. 2014). 
In addition, decrease in rainfall and increased droughts' frequency have contributed to the degradation of rangelands in the HPEM, which has also been caused by overgrazing, plowing and anarchic cultivation of marginal areas, uncontrolled land clearing and sedentarization (Mahyou et al. 2010; Maâtougui et al. 2011; Schilling et al. 2012). Furthermore, climate change and extreme weather events, especially, have often limited the success and sustainability of local public interventions in terms of development and poverty reduction.

To deal with or overcome the negative impacts of climate variability and change, livestock herders in the HPEM have undertaken a diversified range of coping and adaptation practices such as pastoral mobility (transhumance), reciprocal grazing agreements with distant pastoral tribes, rearing of mixed species herds, social networks, and intracommunity solidarity to mitigate income shocks (Bourbouze 2000; Bourbouze and El Aich 2000; Schilling et al. 2012). Complementing these traditional coping actions, contemporary adaptation strategies, which are widely implemented in the study area, include: association of cereal crops and livestock farming, breeding of mixed herds of sheep and goats, new form of mobility based on motorization, income diversification and use of emigrants' remittances, commercializing of livestock, storage of livestock feed, using subsidized livestock feed and public programs against drought effects, sale of animals to purchase supplementary livestock feed (Bourbouze 2000; Bourbouze and El Aich 2000; Schilling et al. 2012), and recently the subscription to insurance climatic multi-risks which covers land cultivated with cereals, but not mobile or sedentary livestock rearing.

Nevertheless, these adaptation strategies are in large part of curative scope, low efficient and are less sustainable over time (Bourbouze 2000; Bourbouze and El Aich 2000). In addition, many of these adaptive practices show a relative or low relevance regarding to the specific objective of adapting to climate change and extremes, since they are seen rather as alternative livelihoods more than adaptation actions itself. Thus, they are undertaken by some breeders in order to secure or diversify their livelihoods, for instance, casual work, emigration and the practice of income-generating activities in complement to livestock rearing.

In addition, the adaptive capacity of the herders in the HPEM's area to climate variability and changes depends on the size of the livestock held and the financial and material resources available. So, their adaptive behaviors rely on their respective socioeconomic status (Bechchari et al. 2014). Thereby, small-scale breeders have less options for adaptation, are more severely affected by the observed adverse climatic trends, and are more threatened by the abandonment of livestock rearing (Bourbouze 2000). More globally, Lazarev (2008) pointed out that the main criteria for differentiation between categories of breeders in the study area are socioeconomic characteristics such as the size of the herd exploited and the capital available. Similarly, it is accepted that the susceptibility to the effects of CC and the adaptation capacities differ according to the farmers. In fact, since that the farmers' CC adaptation depends on their respective specific socioeconomic conditions (Below et al. 2012), the design of an effective and appropriate adaptation CC policy and strategies, must take into consideration these differences within human contexts (Fussel 2007) by using local-level analyses (Below et al. 2012). 
In view of all of the above, the study is aimed at filling the knowledge gaps relating to the adaptation of breeders in the study area to $\mathrm{CC}$, mainly with regard to the effect of social differentiation within livestock herders on the adoption (implementation) of adaptation strategies to this phenomenon. Concretely, the specific objective is to analyze breeders' practices in adapting to climate variability and change, by taking into account their contrasting socioeconomic conditions mainly the existing differences in the size of the sheep flock in ownership.

\section{Materials and Methods}

\section{Study Area}

Located in the northeast of the country (30S UTM zone), the high plateaus of eastern Morocco (HPEM) are one of the largest pastoral areas in Morocco, covering about 3.5 million hectares. Their soils are generally shallow, low in organic matter and therefore susceptible to wind and water erosion (Mahyou et al. 2016). Water resources are very limited. The HPEM have two gradients going from north to south: the altitude increases regularly from 900 to $1400 \mathrm{~m}$ and the climate fluctuates from semi-arid to lower arid and pre-Saharan. Indeed, the climate is of Mediterranean type, but under of a great influence of the Sahara. Average annual rainfall is highly variable, ranging from $143 \mathrm{~mm}$ in the south to $201 \mathrm{~mm}$ in the north, with respective coefficients of variation of $45 \%$ and $34 \%$ (Melhaoui et al. 2018). Dry and hot winds which can cause real sandstorms, especially in summer, are frequent. The rangelands of the HPEM are dominated by specific steppe vegetation consisting of steppes at Stipa tenacissima, Chamemic steppes at Artemisia herba alba and steppes at Chenopodiaceae (Artrophytum scoparium). The vast majority of local population derive most of their income from livestock farming, in particular sheep breeding. The herds in the possession of the breeders in the study area are made up of more than two million heads of small ruminants, usually conducted according to an extensive to semi-extensive rearing system. The HPEM area can be seen as a suitable and representative site for better understanding of adaptation to CC in Morocco's pastoral ecosystems.

\section{Data Collection}

Data collection method consisted of a literature review and a survey of 167 breeders, heads of pastoralist households. Relevant literature available from local extension and agricultural development agencies were consulted to acquire a complete and clear overview about the CC issue in the HPEM's area, mainly with regard to livestock practices and core endogenous adaptation measures implemented by the breeders in response to climate variability and change. The survey of herders focused on the socioeconomic characteristics of households and the adaptation practices embraced to reduce the effects of perceived CC. The basic study unit is the 
pastoralist household, as at this level, decisions relating to adaptation to climate variability and change are taken (Below et al. 2012).

Given that sheep farming is the main activity of the pastoralist households in the study area, the size of the sheep flock in ownership was chosen as the criterion of discrimination between herders. Thereby, three classes of livestock breeders have been identified and this in agreement with local agricultural extension agencies. Large breeders are those with a sheep herd exceeding 300 heads, medium breeders with own sheep flocks of between 101 and 300 heads and the small livestock owners with the number of sheep in possession is less than or equal to 100 heads. Based on the respective representativeness of these three breeders' categories in the study area (Bechchari et al. 2014), respondent herders were randomly selected. The distribution of breeders surveyed by class is as follows: 96 small, 47 medium, and 24 large breeders to give a total of 167 livestock producers.

\section{Data Analysis}

Data collected on the adaptation practices implemented by the livestock herders in the study area were analyzed using descriptive statistics and the tests of Kruskal-Wallis, Mann-Whitney U and of Chi-square independence. Descriptive statistics have been made, with regard to the socioeconomic characteristics of breeders surveyed and the different local adaptation measures. The Chi-square independence test was used to highlight the relationship that may exist between the developed endogenous practices and the categories of herders (small, medium, large). In addition, the strength of this possible statistical association was measured using Cramer's V. coefficient. This test was also carried out to verify whether the observed differences within the three breeders' classes is linked to their respective socioeconomic conditions at household level. Furthermore, Kruskal-Wallis test is an appropriate nonparametric test for comparing more than two independent samples. It is a rank-based test which can be used to test whether such samples come from the same distribution (Ostertagova et al. 2014). The null hypothesis is the following: all the populations have the same median or no significant difference between the groups (samples). In our case, the Kruskal-Wallis test was used to testing for difference in the frequency of adoption of adaptation strategies among three livestock breeders' classes. If the Kruskal-Wallis statistic is significant, a nonparametric multiple comparison method (Mann-Whitney U test) is used to find out which classes of herders are different from the others. Also, using the Mann-Whitney $U$ test, we assessed if the adoption of adaptation practices to CC differed significantly between the three classes of breeders which are based on the size of the owned sheep herd. Indeed, this test was realized to show if there is a significant difference between the "adoptive" and "non-adoptive" groups according to the number of sheep in possession. Generally, the Mann-Whitney U test is a non-parametric statistical test used to determine if two independent samples come from the same population or from 2 different populations. Indeed, this test was used because the assumptions of use of the Student's t test were not verified (non-comparable variances and non-normal distribution of the dependent variable). 


\section{Results and Discussion}

\section{Socioeconomic Characteristics of Breeders Surveyed}

The average age of breeders is 52 years with almost $60 \%$ of them who have an age greater than or equal to 50 years. Livestock breeders are in large part without level of education $(70 \%)$. The rearing of small ruminants is the main economic activity for $83 \%$ of herders sampled. Approximately $35 \%$ of respondents are engaged in an ancillary activity (mainly the temporary employment: $26 \%$ ). The size of households is an average of 8 people. The average number of labor force by household is around 2 persons. The employ of shepherds is observed in $36 \%$ of cases. The rate of emigration is low and is close to $17 \%$. The types of dominant habitat are the tents and concrete houses with respectively $36 \%$ and $24 \%$. The rate of connection to the public electricity network is low, either almost $20 \%$. The distance to the nearest market is relatively long and is $60 \mathrm{~km}$.

The majority of the breeders ( $83 \%$ ) had agricultural land, but only $16 \%$ of the herders surveyed owned an irrigated plot. In effect, on average, arable land was about 31 ha and irrigated area did not exceed the 0.37 ha. Breeders are moderately equipped, since more than $61 \%$ of them possesses at least one agricultural equipment and/or transport (possession trucks: $27 \%$, tractors: $14 \%$ and water tanks: $50 \%$ ). The average number of sheep and goats are respectively of 166 and 33 heads/breeder. More than $52 \%$ of the herders have at least one head of bovine cattle.

Access to formal credit is low not exceeding $23 \%$.

\section{Analysis of Pastoralists Adaptation Practices in the HPEM}

Table 1 showed that the breeders in the HPEM have implemented, over time, a wide and diversified range of adaptation practices to cope with the harmful effects of hazards and climate changes.

These adaptation and coping measures are almost all of endogenous origin, thus attesting on a great intrinsic capacity for adaptation based on the accumulation of experiences and initiatives of the breeders in this arid pastoral ecosystem where climatic conditions are difficult and unpredictable. Local adaptation practices to climate variability and change can be grouped into two main categories: (1) Adjustment of farm management and pastoral practices and (2) Partial shift to alternative livelihood options. A large part of the adaptation actions identified concerns the first dimension.

Contemporary adaptive strategies in the study area are mostly individualized. This testifies to the spectacular rise of an individualism of spirit and action and of refocusing on the individual to the detriment of the social group to which he belongs (Bourbouze and El Aich 2000). These authors added that it is now at the individual level that one must know how to protect oneself from environmental and economic risks and no longer at the community level. Whereas during the first half of the last century, local customary institutions organized the access and use of collective 
Table 1 Distribution of herders surveyed according to adaptive measures implemented (in \%)

\begin{tabular}{|c|c|c|c|c|c|}
\hline Adaptation practices & Freq. & Perc. & Dur. & Inten. & Adeq. \\
\hline \multicolumn{6}{|c|}{ (1) Adjustment of farm management and pastoral practices } \\
\hline Mixed livestock crop farming system & 139 & 83.2 & LT & $\mathrm{P}$ & M \\
\hline Profit of state agricultural programs & 132 & 79 & ST & $\mathrm{C}$ & M \\
\hline Diversification of livestock species & 130 & 77.8 & LT & $\mathrm{P}$ & M \\
\hline Climate multi hazard insurance & 80 & 47.9 & ST & $\mathrm{C}$ & $\mathrm{H}$ \\
\hline Storage of animal feed & 80 & 47.9 & ST & $\mathrm{C}$ & $\mathrm{H}$ \\
\hline Herd mobility & 67 & 40.1 & ST & $\mathrm{C}$ & $\mathrm{H}$ \\
\hline Regular Sale of animals to stock up on feed & 79 & 47.3 & ST & $\mathrm{C}$ & $\mathrm{L}$ \\
\hline Sale of the animal in a good physical state & 73 & 43.7 & LT & $\mathrm{P}$ & M \\
\hline Practice of fattening & 51 & 30.5 & ST & $\mathrm{C}$ & M \\
\hline Credit from speculators livestock feed & 37 & 22.2 & ST & $\mathrm{C}$ & $\mathrm{L}$ \\
\hline Privative appropriation of rangelands & 30 & 18 & ST & $\mathrm{C}$ & M \\
\hline Irrigated agriculture and livestock integration & 22 & 13.2 & LT & $\mathrm{P}$ & $\mathrm{H}$ \\
\hline \multicolumn{6}{|l|}{ (2) Partial shift to alternative livelihood options } \\
\hline Conversion of livestock capital into land capital & 67 & 40.1 & LT & $\mathrm{P}$ & $\mathrm{L}$ \\
\hline Casual labor & 55 & 32.9 & ST & $\mathrm{C}$ & $\mathrm{L}$ \\
\hline Internal or external emigration in search of jobs & 28 & 16.8 & LT & $\mathrm{P}$ & $\mathrm{L}$ \\
\hline Collection of truffles as additional income & 14 & 8.4 & ST & $\mathrm{C}$ & $\mathrm{L}$ \\
\hline
\end{tabular}

Freq.: Frequency. Perc.: Percentage. Duration: ST (Short term); LT (Long term). Intention: C (Curative action); P (Preventive action). Adequacy: H: High; M: Medium; L: Low

pastoral resources and guaranteed intra- and inter-tribal solidarity for the survival of their ethnic groups in times of climate crisis. The decline of these traditional structures for several decades has been caused mainly by a public policy which has fragmented tribal organizations in favor of modern administrative and elected institutions and encouraged sedentarization (Rachik 2007). Negative practices of breeders, especially the large and influential among them, such as the cultivation of rangelands and their appropriation for private use, have also contributed to the weakening of these tribal structures (Bourbouze 2000; Bechchari et al. 2014).

In addition, the majority of the adaptation measures adopted are part of a shortterm temporal perspective, thus allowing breeders to buffer climate risks and reduce their negative consequences through the practices of curative type (for example the regular sale of animals to purchase livestock feed, benefit from public interventions such as subsidized fodder). This testifies to the predominance of short-term and reactive vision of adaptation at local level. Furthermore, most local adaptive practices show a low to medium adequacy in relation to the main objective of adaptation to $\mathrm{CC}$, as their purpose is not a specific response to this phenomenon. They are embraced by breeders either to improve their rearing productivity and, thus, contribute to reducing their vulnerability to hazards and hostile climatic changes, such as diversification of livestock species and practice of fattening (medium adequacy) or to increase their income, meet the financial needs of their farms and maintain their economic activity, e.g., regular sale of animals to purchase livestock feed, credit from resellers of livestock feed and casual employment (low adequacy). Only four 
adaptation measures which were highly relevant in relation to climate change. They are: transhumance or herd mobility, storage of livestock feeds, subscription to climate insurance and the integration of livestock breeding and irrigated agriculture. However, these adaptive actions depend on the socioeconomic status of the breeder (mostly implemented by large herders) or they are very spatially localized like irrigated agriculture.

In line with our findings, Bourbouze (2000) and Bourbouze and El Aich (2000) highlighted that most adaptation practices to variability and climatic risks (drought in particular) implemented by the breeders in the HPEM are of curative type and provide only relative protection. The only really effective strategies against climatic hazards were the cereal-livestock association, livestock feed supplements purchased through animal sales, remittances of emigrants and irrigated agriculture by pumping, but even these are little effective in a sustainable way. Bechchari et al. (2014) emphasized that the adaptive capacity of herders in the HPEM's area with regard to climate-related risks and changes, closely depends on their respective socioeconomic characteristics. In fact, the socioeconomic status of breeders in the study area largely affects their drought adaptation responses and more generally their pastoral practices and their way of using the rangelands (Mahdi 2007; Lazarev 2008).

\section{Differentiation of Adaptation Measures According to Breeders' Classes}

The Table 2 showed general divergence in the frequencies of adaptation measures implemented within the categories of breeders (small, medium and large) which are based on the size of the sheep flock in ownership. Thus, large livestock owners adopt with higher frequencies, most of the endogenous adaptation practices in response to perceived climate variability and change, compared to the two other categories. In addition, practices of the first dimension of adaptation measures are more frequently implemented by large breeders. They include strategies for the diversification of the productions (integration of livestock breeding and cereal farming, breeding of mixed flocks of sheep and goats), improvement of rearing productivity (practice of the fattening, selection and reproduction of powerful races), transhumance and market orientation (finished products of good taste quality). In fact, all of these adaptation strategies require considerable financial resources, which manifests itself in much lower adoption frequencies among small and medium-sized breeders.

By relying on their social status and their relationship networks, large breeders adopt an opportunistic land strategy by constantly conquering vast new areas of collective rangelands for their private use. As evidenced by the significant differences between the average available agricultural areas, which are 86, 37 and 15 hectares respectively for great, medium and small breeders. Recently, large herders and some medium breeders have massively subscribed to climatic multi-risk insurance. The adoption of this practice has two objectives. First, climate insurance contracts represent, in the eyes of local breeders, justifications approving the legitimacy of the ownership of conquered rangelands in order to annex them definitively 
Table 2 Frequencies of adaptation measures in percentage according to breeders' classes and results of the Chi-square independence test

\begin{tabular}{|c|c|c|c|c|c|}
\hline Adaptation practices & $\begin{array}{l}\text { Small (n } \\
=96)\end{array}$ & $\begin{array}{l}\text { Medium (n } \\
=47)\end{array}$ & $\begin{array}{l}\text { Large }(\mathrm{n} \\
=24)\end{array}$ & $\chi^{2}$ Pearson & $\begin{array}{l}\text { Cramer's } \\
\text { V }\end{array}$ \\
\hline $\begin{array}{l}\text { Mixed livestock crop } \\
\text { farming system }^{\mathrm{a}}\end{array}$ & 74 & 93.6 & 100 & $14.384(0.001)$ & $0.293^{\mathrm{M}}$ \\
\hline $\begin{array}{l}\text { Profit of state } \\
\text { agricultural programs }\end{array}$ & 75 & 83 & 87.5 & $2.423(0.298)$ & $0.120^{\mathrm{L}}$ \\
\hline $\begin{array}{l}\text { Diversification of } \\
\text { livestock species }\end{array}$ & 71.9 & 85.1 & 87.5 & $4.718(0.095)$ & $0.168^{\mathrm{L}}$ \\
\hline $\begin{array}{l}\text { Climate multi hazard } \\
\text { insurance }^{\mathrm{a}}\end{array}$ & 28.1 & 70.2 & 83.3 & $36.493(0.000)$ & $0.467^{\mathrm{S}}$ \\
\hline Storage of animal feed ${ }^{\mathrm{a}}$ & 36.5 & 63.8 & 62.5 & $11.865(0.003)$ & $0.267^{\mathrm{M}}$ \\
\hline Herd mobility $^{\mathrm{a}}$ & 27.1 & 48.9 & 75 & $20.466(0.000)$ & $0.350^{\mathrm{M}}$ \\
\hline $\begin{array}{l}\text { Regular Sale of animals } \\
\text { to stock up on feed }\end{array}$ & 44.8 & 53.2 & 45.8 & $0.917(0.632)$ & $0.074^{\mathrm{L}}$ \\
\hline $\begin{array}{l}\text { Sale of the animal in a } \\
\text { good physical state }\end{array}$ & 33.3 & 48.9 & 75 & $14.273(0.001)$ & $0.292^{\mathrm{M}}$ \\
\hline Practice of fattening ${ }^{\mathrm{a}}$ & 20.8 & 31.9 & 66.7 & $19.072(0.000)$ & $0.338^{\mathrm{M}}$ \\
\hline $\begin{array}{l}\text { Credit from speculators } \\
\text { livestock feed }\end{array}$ & 18.8 & 19.1 & 41.7 & $6.189(0.045)$ & $0.193^{\mathrm{L}}$ \\
\hline $\begin{array}{l}\text { Privative appropriation } \\
\text { of rangelands } \mathrm{s}^{\mathrm{a}}\end{array}$ & 13.5 & 17 & 37.5 & $7.518(0.023)$ & $0.212^{\mathrm{M}}$ \\
\hline $\begin{array}{l}\text { Irrigated agriculture } \\
\text { and livestock } \\
\text { integration }\end{array}$ & 8.3 & 21.3 & 16.7 & $4.920(0.085)$ & $0.172^{\mathrm{L}}$ \\
\hline $\begin{array}{l}\text { Conversion of } \\
\text { livestock capital into } \\
\text { land capital }\end{array}$ & 29.2 & 44.7 & 75 & $17.355(0.000)$ & $0.322^{\mathrm{M}}$ \\
\hline Casual labor $^{\mathrm{a}}$ & 42.7 & 27.7 & 4.2 & $13.736(0.001)$ & $0.287^{\mathrm{M}}$ \\
\hline $\begin{array}{l}\text { Internal or external } \\
\text { emigration in search of } \\
\text { jobs }\end{array}$ & 13.5 & 21.3 & 20.8 & $1.685(0.431)$ & $0.100^{\mathrm{L}}$ \\
\hline $\begin{array}{l}\text { Collection of truffles as } \\
\text { additional income }\end{array}$ & 13.5 & 2.1 & 0 & $7.917(0.019)$ & $0.218^{\mathrm{M}}$ \\
\hline
\end{tabular}

Note: Cramer's V. value: S: Strong (between 0.40 and 0.80); M: Moderate (between 0.20 and 0.40); L: Low (between 0.10 and 0.20 ). Values in parentheses in $\chi^{2}$ Pearson represent the asymptotic significance (bilateral)

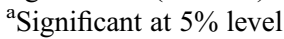

later. Also, this measure (insurance) allows subscribers significant financial compensation following of climatic hazards (drought in particular) equals to $600 \mathrm{MAD}$ per hectare.

Large livestock owners have benefited from contracts of sale with supermarkets of many urban agglomerations in the north of the country during the feasts of sacrifice, thanks to the USAID' initiative. Thus, they were able to achieve very interesting butcher performances (well-finished animal products with appreciable gustative qualities). This explains the strong orientation of their breeding 
activity towards the market. In addition, thanks to their accumulated savings, large livestock keepers invest more and more in activities of speculation, including the real estate, in order to overcome the unfavorable climatic and economic conditions affecting their livestock rearing activity.

As for small herders, they frequently shift to additional off-farm livelihoods to complete or diversify their income sources. Thus, they are forced to engage in other small-scale activities in addition to the livestock breeding, such as temporary labor, collecting truffles and small trades, in order to satisfy both the needs of their families and those of their meager herds especially in the event of climatic vagaries (drought) prolonged in time. The poorest of them, after the sale of all their herds, find themselves decapitalized. In the absence of support from relatives or the State, they opt for rural exodus as the final solution.

In addition, the results of the Chi-square independence test revealed that there was a statistically significant relationship between most adaptation practices (11/16 measures identified) and livestock breeders' classes (Table 2). The Cramer's V. coefficient measuring the strength of this statistical relationship has medium to high values. This association of significant magnitude indicates, thereby, that the larger the size of the sheep herd in possession, the higher the frequency of adoption (implementation) of adaptation practices.

As highlighted by Bourbouze (2000), the choices for small breeders regarding adaptation to adverse impacts of climate variability and extremes are much narrower and their most common strategy is to regularly sell animals in the souk so that they can buy livestock feed, water their herds and feed their families. Thereafter, either they abandon livestock rearing after having sold all their flocks, or they migrate to the nearest urban centers in search of small trades. Whereas the decapitalization strategy seems well controlled among large breeders (Bourbouze and El Aich 2000), they can even take advantage of periods of climatic crisis to increase the size of their herds to the detriment of the poorest breeders (Schilling et al. 2012). Bechchari et al. (2014) underlined that the portfolio of strategies for adapting to variability and climate change implemented by large breeders is much denser and more diversified. It includes the acquisition of equipment (trucks, tractors, water tanks), the appropriation of large areas of rangelands, the profit of the best grazing sites and the commercial speculation in livestock in order to make a good profit on their invested capitals. In contrast, the possibilities offered for small breeders, are very limited and mainly boil down to the regular sale of their herds, the search for additional activities to breeding and rural exodus.

The Kruskal-Wallis test was conducted to examine the differences in the frequency of adoption of climate change adaptation practices according to the classes of breeders. Significant differences (chi square $=8.1123, p=0.017, \mathrm{df}=2$ ) were found between the three categories of herders. In addition, the distribution of the majority of adaptive measures differs significantly between classes of breeders (Table 3).

After the Kruskal-Wallis test led us to reject the null hypothesis of similarity between breeders' categories in terms of frequency of adoption of adaptation and coping actions, we performed pairwise comparisons using the Mann-Whitney test to 
Table 3 Results of the Kruskal-Wallis test

\begin{tabular}{l|l|l}
\hline Adaptation practices & Chi-square value & Sig-p \\
\hline Mixed livestock crop farming system** & 14.298 & 0.001 \\
\hline Profit of state agricultural programs & 2.408 & 0.300 \\
\hline Diversification of livestock species & 4.690 & 0.096 \\
\hline Climate multi hazard insurance*** & 36.275 & 0.000 \\
\hline Storage of animal feed** & 11.794 & 0.003 \\
\hline Herd mobility*** & 20.344 & 0.000 \\
\hline Regular Sale of animals to stock up on feed & 0.912 & 0.634 \\
\hline Sale of the animal in a good physical state** & 14.187 & 0.001 \\
\hline Practice of fattening*** & 18.958 & 0.000 \\
\hline Credit from speculators livestock feed* & 6.152 & 0.046 \\
\hline Privative appropriation of rangelands* & 7.473 & 0.024 \\
\hline Irrigated agriculture and livestock integration & 4.891 & 0.087 \\
\hline Conversion of livestock capital into land capital*** & 17.251 & 0.000 \\
\hline Casual labor** & 13.654 & 0.001 \\
\hline Internal or external emigration in search of jobs & 1.675 & 0.433 \\
\hline Collection of truffles as additional income* & 7.869 & 0.020
\end{tabular}

Note: Significance: ${ }^{* * *} P<0.01,{ }^{*} * P<0.05,{ }^{*} P<0.1$; Degree of freedom $=2$

determine which classes of breeders are different. The results of this test show that there is a highly significant difference $(U$ statistic $=58.000, p=0.008)$ between small and large breeders in adopting $\mathrm{CC}$ adaptation practices. The other differences between on the one hand small and medium breeders $(\mathrm{U}=92.000, p=0.174)$ and between medium and large herders on the other hand $(\mathrm{U}=79.500, p=0.067)$ were found not to be significant. This shows that breeders' adaptation in the study area depends mainly on their social status or economic power, expressed by the size of the sheep herd in possession.

\section{Factors Influencing the Adoption of Climate Change Adaptation Practices}

In order to confirm this relationship between the adaptation measures to climate variability and change implemented by the breeders in the study area and the size of the sheep herd in possession, we carried out the Mann-Whitney $U$ test. This test is often employed to compare differences between two independent groups when the dependent variable is continuous, but not normally distributed. In our case, the two independent groups are the "adopters" and "non-adopters" of CC adaptation practices, while the continuous dependent variable is the sheep herd size. The mean rank column shows mean rank for the two groups tested (adopters and non-adopters groups). This column is very useful because it indicates which group can be considered as having the higher size of sheep herd, overall; namely, the group with the highest mean rank. In this case, the adopter group had the highest size of sheep herd. Indeed, the first group (adopters) have higher mean ranks than those of 
non-adopters, except for the case of two coping actions, namely, "Casual labor" and "Collection of truffles as additional income" (Table 4). In fact, these two practices are usually pursued either as a complement to a breeding activity that does not allow the household to meet its needs or in the event of abandonment of livestock farming (decapitalization frequently caused by successions of prolonged episodes of drought). They are practiced mainly by the small breeders with respectively 75 and $93 \%$.

Furthermore, the Test Statistics column shows us the actual significance value of the Mann-Whitney U test. Specifically, this column provides the test statistic, U statistic, as well as the asymptotic significance p-value. From our data, it can be

Table 4 Mann-Whitney $U$ test showing the relationship between sheep herd size and adaptive practices

\begin{tabular}{|c|c|c|c|c|}
\hline \multirow[b]{2}{*}{ Adaptation practices } & \multicolumn{2}{|c|}{ Mean rank } & \multirow[b]{2}{*}{$(\mathrm{U}, p)$} & \multirow[b]{2}{*}{ Z } \\
\hline & Yes & No & & \\
\hline Mixed livestock crop farming system & 92.64 & 41.11 & $(745,0.000)$ & -5.149 \\
\hline Profit of state agricultural programs & 87.16 & 72.07 & $\begin{array}{l}(1892.5 \\
0.100)\end{array}$ & -1.643 \\
\hline $\begin{array}{l}\text { Diversification of livestock species (sheep \& } \\
\text { goats) }\end{array}$ & 90.33 & 61.76 & $\begin{array}{l}(1582 \\
0.002)\end{array}$ & -3.174 \\
\hline Climate multi hazard insurance & 105.35 & 64.37 & $\begin{array}{l}(1772 \\
0.000)\end{array}$ & -5.476 \\
\hline Storage of animal feed & 96.01 & 72.96 & $\begin{array}{l}(2519.5 \\
0.002)\end{array}$ & -3.079 \\
\hline Herd mobility & 107.60 & 68.19 & $\begin{array}{l}(1768.5 \\
0.000)\end{array}$ & -5.168 \\
\hline Regular Sale of animals to stock up on feed & 91.88 & 76.93 & $\begin{array}{l}(2853.5 \\
0.046)\end{array}$ & -1.997 \\
\hline Sale of the animal in a good physical state & 100.18 & 71.44 & $\begin{array}{l}(2250 \\
0.000)\end{array}$ & -3.813 \\
\hline Practice of fattening & 105.96 & 74.34 & $\begin{array}{l}(1838 \\
0.000)\end{array}$ & -3.895 \\
\hline Credit from speculators livestock feed & 98.43 & 79.89 & $\begin{array}{l}(1871 \\
0.039)\end{array}$ & -2.059 \\
\hline Privative appropriation of rangelands & 106.17 & 79.15 & $\begin{array}{l}(1390, \\
0.006)\end{array}$ & -2.774 \\
\hline Irrigated agriculture and livestock integration & 97.68 & 81.92 & $\begin{array}{l}(1294, \\
0.154)\end{array}$ & -1.425 \\
\hline $\begin{array}{l}\text { Conversion of livestock capital into land } \\
\text { capital }\end{array}$ & 101.54 & 72.25 & $\begin{array}{l}(2174.5 \\
0.000)\end{array}$ & -3.841 \\
\hline Casual labor & 59.39 & 96.08 & $\begin{array}{l}(1726.5 \\
0.000)\end{array}$ & -4.612 \\
\hline $\begin{array}{l}\text { Internal or external emigration in search of } \\
\text { jobs }\end{array}$ & 94.36 & 81.91 & $\begin{array}{l}(1656, \\
0.214)\end{array}$ & -1.243 \\
\hline Collection of truffles as additional income & 27.46 & 89.17 & $\begin{array}{l}(279.5 \\
0.000)\end{array}$ & -4.574 \\
\hline
\end{tabular}

Note: $\mathrm{U}$ : $\mathrm{U}$ statistic of Mann-Whitney test, $p$ : the value of $\mathrm{p}$ of the test 
concluded that the size of the sheep herd in the adopter group was significantly higher than in the non-adopter group for the majority of adaptation strategies practiced by the livestock owners in the study area.

In line with our findings, herd size influences positively and significatively the likelihood that pastoralists implement adaptation strategies in the face of climate change (Balew et al. 2014; Berhanu and Beyene 2015; Opiyo et al. 2015).

Other socioeconomic characteristics at household-level, using the category of the breeder as a classification variable, could explain significant observed differences in the frequency of climate change adaptation practice's adoption (implementation) within breeders' classes (small, medium, large). The results of chi-square independence test contained in the Table 5 show that there is a significant relationship between the category of herder and the following factors: age of breeder $\left(\chi^{2}=19.020, p=0.000\right)$, household size $\left(\chi^{2}=30.720, p=0.000\right)$, no practice of ancillary activity $\left(\chi^{2}=25.662, p=0.000\right)$, employment of shepherds $\left(\chi^{2}=42.124\right.$, $p=0.000)$, land ownership $\left(\chi^{2}=14.384, p=0.001\right)$, possession of truck $\left(\chi^{2}=17.754, p=0.000\right)$, possession of tractor $\left(\chi^{2}=49.740, p=0.000\right)$, possession of water tank $\left(\chi^{2}=33.902, p=0.000\right)$, possession of a motor pump $\left(\chi^{2}=39.048\right.$, $p=0.000)$, veterinary care $\left(\chi^{2}=16.005, p=0.000\right)$, training received $\left(\chi^{2}=7.850\right.$, $p=0.020)$ and membership to a technical supervisory structure, namely, National Association of sheep and goat breeders- ANOC $\left(\chi^{2}=27.454, p=0.000\right)$.

Large livestock producers have a higher average age, 62 years, compared to 49 years for small breeders (Table 6). They are ones who benefited the most from training actions in livestock rearing, development and management of rangelands and other technical topics of interest ( $42 \%$ vs. $17 \%$ ), adhered massively to the breeders' organization, namely, ANOC (58\% vs. $11 \%)$. These elements indicate that large herders have accumulated a great pastoralism experience compared to small-scale breeders. Piya et al. (2013) and Tiwari et al. (2014) pointed out that the training received improved the adaptive capacity of farmers in the face of climate change. As highlighted by Tiwari et al. (2014) and Taruvinga et al. (2016), membership in the community-based organizations increases the adoption of climate change coping strategies. Yila and Resurreccion (2013) and Mabe et al. (2014) underlined that farming experience significantly and positively influences the implementation of CC measures, respectively in the semiarid Nguru Local Government Area, Northeastern Nigeria, and in Northern Ghana. In addition, large breeders are far largely more endowed with production factors than small breeders such as labor force (4 vs.. 1 people), employment of shepherds ( 88 vs. 19\%), land size ( 86 vs. $15 \mathrm{ha}$ ), small ruminants herd size (684 vs. 72 heads), bovine cattle flock size (7 vs. 1 head), number of equipment owned ( 5 vs. 1 ) and veterinary care ( 83 vs. $45 \%$ ). In line with our findings, Yila and Resurreccion (2013) pointed out that labor force was a significant determinant for farmers' adaptation practices to climate change in the semiarid Nguru Local Government Area, Northeastern Nigeria. Debalke (2011) and Ndamani and Watanabe (2016) highlighted that land size was a determinant factor that influences farmers' climate change coping strategies, respectively, in north shoa zone of Amhara region Ethiopia and Lawra district of Ghana. Berhanu and Beyene (2015) and Opiyo et al. (2015) have found that herd size affected positively and 
Table 5 Significant factors (categorical variables) explaining the differences observed in the frequency of adoption of adaptation practices between categories of breeders

\begin{tabular}{|c|c|c|c|c|c|}
\hline Categorical variables & $\begin{array}{l}\text { Small } \\
(\%)\end{array}$ & $\begin{array}{l}\text { Medium } \\
(\%)\end{array}$ & $\begin{array}{l}\text { Large } \\
(\%)\end{array}$ & $\begin{array}{l}\text { Chi-square } \\
\text { value }\end{array}$ & Sig-p \\
\hline Age & & & & 19.020 & 0.000 \\
\hline$<50$ years & 54 & 32 & 8 & & \\
\hline$>=50$ years & 46 & 68 & 92 & & \\
\hline Ancillary activity & & & & 25.662 & 0.000 \\
\hline Yes & 47 & 28 & 8 & & \\
\hline No & 53 & 72 & 92 & & \\
\hline Household size & & & & 30.720 & 0.000 \\
\hline$<8$ people & 70 & 38 & 12 & & \\
\hline$>=8$ people & 30 & 62 & 88 & & \\
\hline $\begin{array}{l}\text { Employment of } \\
\text { shepherds }\end{array}$ & & & & 42.124 & 0.000 \\
\hline Yes & 19 & 47 & 88 & & \\
\hline No & 81 & 53 & 12 & & \\
\hline Land ownership & & & & 14.384 & 0.001 \\
\hline Yes & 74 & 94 & 100 & & \\
\hline No & 26 & 6 & 0 & & \\
\hline Favorable pastures & & & & 12.160 & 0.002 \\
\hline Yes & 14 & 36 & 38 & & \\
\hline No & 86 & 64 & 62 & & \\
\hline Equipment & & & & 20.399 & 0.000 \\
\hline Yes & 50 & 64 & 100 & & \\
\hline No & 50 & 36 & 0 & & \\
\hline Possession of truck & & & & 17.754 & 0.000 \\
\hline Yes & 17 & 32 & 58 & & \\
\hline No & 83 & 68 & 42 & & \\
\hline Possession of tractor & & & & 49.740 & 0.000 \\
\hline Yes & 2 & 17 & 58 & & \\
\hline No & 98 & 83 & 42 & & \\
\hline Possession of cart & & & & 9.995 & 0.007 \\
\hline Yes & 21 & 2 & 8 & & \\
\hline No & 79 & 98 & 92 & & \\
\hline Possession of tank & & & & 33.902 & 0.000 \\
\hline Yes & 34 & 55 & 100 & & \\
\hline No & 66 & 45 & 0 & & \\
\hline Possession of pump & & & & 39.048 & 0.000 \\
\hline Yes & 12 & 30 & 75 & & \\
\hline No & 88 & 70 & 25 & & \\
\hline Veterinary care & & & & 16.005 & 0.000 \\
\hline Yes & 45 & 70 & 83 & & \\
\hline No & 55 & 30 & 17 & & \\
\hline Training received & & & & 7.850 & 0.020 \\
\hline
\end{tabular}


Table 5 (continued)

\begin{tabular}{c|l|l|l|l|l}
\hline Categorical variables & $\begin{array}{l}\text { Small } \\
(\mathbf{\%})\end{array}$ & $\begin{array}{l}\text { Medium } \\
(\%)\end{array}$ & $\begin{array}{l}\text { Large } \\
(\%)\end{array}$ & $\begin{array}{l}\text { Chi-square } \\
\text { value }\end{array}$ & Sig-p \\
\hline Yes & 17 & 17 & 42 & & \\
\hline No & 83 & 83 & 58 & & \\
\hline BO Membership & & & & 27.454 & 0.000 \\
\hline Yes & 11 & 38 & 58 & & \\
\hline No & 89 & 62 & 42 & & \\
\hline
\end{tabular}

Note: BO: Breeder Organization

Table 6 Significant factors (continuous variables) explaining the differences observed in the frequency of adaptation practices' adoption between categories of breeders

\begin{tabular}{|c|c|c|c|c|c|}
\hline Variable & Category & Minimum & Maximum & Mean & $\begin{array}{l}\text { Standard } \\
\text { deviation }\end{array}$ \\
\hline \multirow[t]{3}{*}{ Age } & Small & 22 & 85 & 49 & 13.94 \\
\hline & Medium & 24 & 79 & 53 & 12.66 \\
\hline & Large & 44 & 79 & 62 & 8.60 \\
\hline \multirow[t]{3}{*}{ Household size } & Small & 1 & 14 & 6 & 2.63 \\
\hline & Medium & 3 & 16 & 9 & 3.00 \\
\hline & Large & 5 & 23 & 12 & 4.47 \\
\hline \multirow[t]{3}{*}{ Labor force } & Small & 0 & 3 & 1 & 0.93 \\
\hline & Medium & 0 & 6 & 2 & 1.47 \\
\hline & Large & 0 & 12 & 4 & 2.32 \\
\hline \multirow[t]{3}{*}{ Land size } & Small & 0 & 52 & 15 & 14.81 \\
\hline & Medium & 0 & 196 & 37 & 41.05 \\
\hline & Large & 8 & 300 & 86 & 82.68 \\
\hline \multirow[t]{3}{*}{ Equipment } & Small & 0 & 4 & 1 & 1.19 \\
\hline & Medium & 0 & 6 & 2 & 1.77 \\
\hline & Large & 2 & 14 & 5 & 2.96 \\
\hline \multirow{3}{*}{$\begin{array}{l}\text { Small ruminants herd } \\
\text { size }\end{array}$} & Small & 0 & 180 & 72 & 37.31 \\
\hline & Medium & 101 & 500 & 214 & 78.57 \\
\hline & Large & 355 & 1400 & 684 & 260.00 \\
\hline \multirow[t]{3}{*}{ Bovine cattle herd size } & Small & 0 & 10 & 1 & 2.20 \\
\hline & Medium & 0 & 13 & 3 & 3.70 \\
\hline & Large & 0 & 50 & 7 & 10.38 \\
\hline
\end{tabular}

significantly the probability that pastoralists put in place $\mathrm{CC}$ adaptation measures. Hassan and Nhemachena (2008) and Ouédraogo et al. (2010) stressed that ownership of heavy machinery or agricultural equipment improves the coping capacities of farmers to deal with the negative effects of climate variability and extremes.

Furthermore, large breeders have specialized over time in the extensive breeding of small ruminants, while small-scale herders have been forced to practice non-farm activities such as casual labor, small trades, and the collection of truffles to obtain additional income necessary for their survival. In fact, almost all large livestock 
owners $(92 \%)$ do not carry out any ancillary activity generating additional income, unlike $53 \%$ for small herders. Given that the occupation of the farmer was an indication of the total amount of time available for farming activities (Gbetibouo 2009), the off-farm employment may present a constraint to the adoption of technology because it consumes time which must be devoted to the management of agricultural activities (McNamara et al. 1991). Also, large breeders are the ones who benefit most from the best grazing sites (38 vs. 14\%). Berhanu and Beyene (2015) expressed that the traditional pastoralism represents a resilient and unique system of adaptation to hostile and unpredictable climatic variability in dryland ecosystems.

In accordance with the results presented above, several previous studies showed that the significant factors influencing African farmers' adaptation to climate change are socioeconomic household-level variables, and this in many countries such as Ethiopia (Balew et al. 2014; Berhanu and Beyene 2015), South Africa (Taruvinga et al. 2016), Ghana (Ndamani and Watanabe 2016), Tanzania (Below et al. 2012), Nigeria (Obayelu et al. 2014), Kenya (Opiyo et al. 2015), and Uganda (Nabikolo et al. 2012).

\section{Conclusion}

In response to perceived climate changes and extremes, livestock breeders in the high plateaus of eastern Morocco have implemented differently many adaptation practices, depending on their respective socioeconomic conditions at household level. Thereby, contrasting socioeconomic characteristics, mainly the size of sheep flock in ownership, allowed large breeders to adopt (put in place) with higher frequency most of adaptive measures compared to small-scale herders who have much more limited possibilities or choices. This social inequality could be exacerbated in the future due to adverse climatic trends (increase in the frequency and intensity of droughts, reduction in rainfall amounts) caused by current and future climate change, in the absence of support measures targeting primarily small breeders who are the most vulnerable group to this climatic phenomenon.

In addition, future studies relating to climate change adaptation in the study area should first investigate the perceptions of livestock producers. Indeed, local perceptions toward climate change influence farmers' decisions on whether or not to adapt (Deressa et al. 2009), are useful for the development of relevant and appropriate adaptation policies and strategies (Opiyo et al. 2015), and are also an important factor influencing the success of the adaptation actions to be implemented (Tesfahunegn et al. 2016).

\section{References}

Balew S, Agwata J, Anyango S (2014) Determinants of adoption choices of climate change adaptation strategies in crop production by small scale farmers in some regions of Central Ethiopia. J Nat Sci Res 4(4):78-93 
Bechchari A, El Aich A, Mahyou H, Baghdad B, Bendaou M (2014) Etude de la dégradation des pâturages steppiques dans les communes de Maâtarka et Béni Mathar (Maroc oriental). J Mater Environ Sci 5(S2):2572-2583

Below TB, Mutabazi KD, Kirschke D, Franke C, Sieber S, Siebert R, Tscherning K (2012) Can farmers' adaptation to climate change be explained by socioeconomic household-level variables? Glob Environ Chang 22(1):223-235. https://doi.org/10.1016/j.gloenvcha.2011.11.012

Beniston M, Stephenson D, Christensen O et al (2007) Future extreme events in European climate: an exploration of regional climate model projections. Clim Chang 81:71-95

Berhanu W, Beyene F (2015) Climate variability and household adaptation strategies in Southern Ethiopia. Sustainability 2015(7):6353-6375. https://doi.org/10.3390/su7066353

Besada H, Sewankambo N (2009) Climate change in Africa: adaptation, mitigation and governance challenges. CIGI Special Report. Centre for International Governance Innovation $=$ Centre pour l'innovation dans la gouvernance internationale, Waterloo, p 49

Bourbouze A (2000) Pastoralisme au Maghreb: la révolution silencieuse. Fourrages 161:3-21

Bourbouze A, El Aich A (2000) Gestion des parcours et des troupeaux en régions steppiques et réponse à l'aléa climatique. Dans: Guessous F, Rihani N, Ilham A (eds) Livestock production and climatic uncertainty in the Mediterranean. EAAP Publication no 94. Wageningen Pers, Wageningen, pp 307-319

Bruckner M (2012) Climate change vulnerability and the identification of least developed countries (LDCs). The United Nations Development Policy and Analysis Division Department of Economic and Social Affairs. CDP Background Paper no 15, p 29. https://www.un.org/ development/desa/dpad/wp-content/uploads/sites/45/publication/CDP-bp-2012-15.pdf

Bzioui M (2012) Gestion des ressources en eau au Maroc et changement climatique. In: Ellinor ZM, Bennis A (eds) Environnement et changement climatique au Maroc- Diagnostic et Perspectives. Konrad-Adenauer-Stiftung e.V., Bureau au Maroc, Rabat, pp 63-69

Debalke NM (2011) Determinants of farmers' preference for adaptation strategies to climate change: evidence from north shoa zone of Amhara region Ethiopia. MPRA Paper no 48753. Ambo University, Addis Ababa University

Deressa TT, Hassan RM, Ringler C, Alemu T, Yesuf M (2009) Determinants of farmers' choice of adaptation methods to climate change in the Nile Basin of Ethiopia. Glob Environ Chang 19:248-255

Ezouine D, Bouaza N (2019) Climate finance strategy in Morocco. Am J Clim Chang 8:482-501. https://doi.org/10.4236/ajcc.2019.84026

Fink A, Christoph M, Born K et al (2010) Climate. In: Speth P, Christoph M, Diekkrüger B (eds) Impacts of global change on the hydrological cycle in west and Northwest Africa. Springer, Heidelberg, pp 54-58

François A, Gauché E, Génin A (2016) L'adaptation des territoires aux changements climatiques dans l'Oriental marocain: la vulnérabilité entre action et perceptions. VertigO 16(1):1-25. https://doi.org/10.4000/vertigo.17177. http://journals.openedition.org/vertigo/17177

Fussel HM (2007) Adaptation planning for climate change: concepts, assessment approaches, and key lessons. Sustain Sci 2(2):265-275

Garcia D (2008) The climate security divide: bridging human and national security in Africa. Afr Secur Rev 17(3):1-17. https://doi.org/10.1080/10246029.2008.9627480

Gbetibouo GA (2009) Understanding farmers' perceptions and adaptations to climate change and variability - the case of the Limpopo Basin, South Africa. IFPRI Discussion Paper 00849. Centre for Environmental Economics and Policy in Africa, University of Pretoria. http://www. ifpri.org/publication/understanding-farmers-perceptions-and-adaptations-climate-change-andvariability

Hassan RM (2010) Implications of climate change for agricultural sector performance in Africa: policy challenges and research agenda. J Afr Econ 19:77-105. https://doi.org/10.1093/jae/ ejp026

Hassan RM, Nhemachena C (2008) Determinants of African farmers strategies for adapting to climate change: multinomial choice analysis. Afr J Agric Resour Econ 2(1):83-104 
Hulme M, Doherty R, Ngara T, New M, Lister D (2001) African climate change: 1900-2100. Clim Res 17(2):145-168

International Panel on Climate Change (IPCC) (2014) Synthesis report. In: Pachauri RK, Meyer LA (eds) Climate change 2014: contribution of working groups I, II and III to the fifth assessment report of the intergovernmental panel on climate change. Core writing team. IPCC, Geneva. 151pp. https://www.ipcc.ch/site/assets/uploads/2018/05/SYR_AR5_FINAL_full_wcover.pdf

Kuhn A, Heidecke C, Roth A et al (2010) Importance of resource management for livelihood security under climate change in southern Morocco. In: Speth P, Christoph M, Diekkrüger B (eds) Impacts of global change on the hydrological cycle in west and Northwest Africa. Springer, Heidelberg, pp 566-591

Lazarev G (2008) L'élevage pastoral dans les Hauts Plateaux de l'Oriental du Maroc. Les notes d'analyse du CIHEAM 37:1-32

Maâtougui A, Acherkouk M, El Fadili M, Elhoumaizi MA (2011) Les pâturages steppiques de l'Oriental marocain. L'essentiel sur l'état de dégradation et les voies d'amélioration. Division de l'information et de la communication, INRA-Edition, Rabat, pp 1-57

Mabe FN, Sienso G, Donkoh S (2014) Determinants of choice of climate change adaptation strategies in Northern Ghana. Res Appl Econ 6(4):75-94

Mahdi M (2007) Pastoralism and institutional change in the oriental. In: Gertel J, Breuer I (eds) Pastoral Morocco: globalizing scapes of mobility and insecurity. Reichert, Wiesbaden, pp 93105

Mahyou H, Tychon B, Balaghi R, Mimouni J, Paul R (2010) Désertification des parcours arides au Maroc. Tropicultura 28(2):107-114

Mahyou H, Tychon B, Balaghi R, Louhaichi M, Mimouni J (2016) A knowledge-based approach for mapping land degradation in the arid rangelands of North Africa. Land Degrad Dev 27:1574-1585

McNamara KT, Wetzstein ME, Douce GK (1991) Factors affecting peanut producer adoption of integrated pest management. Rev Agric Econ 13:129-139

Melhaoui M, Mezrhab A, Mimouni J (2018) Evaluation et cartographie de la sécheresse météorologique dans les hauts plateaux de l'Oriental du Maroc. Rev Microbiol Ind San Environ 12(1):71-92

Mokssit A (2012) Le point sur le changement climatique au Maroc. In: Ellinor ZM, Bennis A (eds) Environnement et changement climatique au Maroc- Diagnostic et Perspectives-. KonradAdenauer-Stiftung e.V., Bureau au Maroc, Rabat, pp 35-40

Moroccan Meteorological Office (2007) Les changements climatiques au Maroc: Observations et projections. DMN (Direction de la Météorologie nationale). Météo Maroc, Casablanca. https:// www.preventionweb.net/files/changements_climatiques-214.pdf

Morocco (2011) Projet d'intégration du changement climatique dans la mise en œuvre du plan Maroc vert (Project to integrate climate change into the implementation of the Green Morocco Plan). Ministry of Agriculture and Maritime Fisheries and the Agency for Agricultural Development. http://www.ada.gov.ma/uplds/pars/ECIESPICCPMV.pdf

Morocco (2016) $3^{\text {ème }}$ Communication Nationale du Maroc à la Convention Cadre des Nations Unies sur les changements climatiques (The third national communication of Morocco to the United Nations Framework Convention on Climate Change). Ministry Delegate to the Minister of Energy, Mines, Water and Environment in charge of the Environment. https://unfccc.int/ resource/docs/natc/marnc3.pdf

Nabikolo D, Bashaasha B, Mangheni MN, Majaliwa JGM (2012) Determinants of climate change adaptation among male and female headed farm households in eastern Uganda. Afr Crop Sci J 20(s2):203-212

National Intelligence Council (NIC) (2009) North Africa: the impact of CC to 2030 (Selected Countries). A Commissioned Research Report NIC 2009-007D. https://www.dni.gov/files/ documents/climate2030_north_africa.pdf

Ndamani F, Watanabe T (2016) Determinants of farmers' adaptation to climate change: a micro level analysis in Ghana. Sci Agric 73(3):201-208 
Obayelu OA, Adepoju AO, Idowu T (2014) Factors influencing farmers' choices of adaptation to climate change in Ekiti State, Nigeria. J Agric Environ Int Dev 108(1):3-16. https://doi.org/10. 12895/jaeid.20141.140

Opiyo F, Wasonga OV, Nyangito MM, Mureithi SM, Obando J, Munang R (2015) Determinants of perceptions of climate change and adaptation among Turkana pastoralists in northwestern Kenya. Clim Dev. https://doi.org/10.1080/17565529.2015.1034231

Ostertagova E, Ostertag O, Kováč J (2014) Methodology and application of the Kruskal-Wallis test. Appl Mech Mater 611:115-120

Ouédraogo M, Dembélé Y, Somé L (2010) Perceptions et stratégies d'adaptation aux changements des précipitations: cas des paysans du Burkina Faso. Sécheresse 21(2):87-96. https://doi.org/10. $1684 / \mathrm{sec} .2010 .0244$

Paeth H, Born K, Girmes R et al (2009) Regional climate change in Tropical and Northern Africa due to greenhouse forcing and land use changes. J Clim 22:114-132

Piya L, Maharjan KL, Joshi NP (2013) Determinants of adaptation practices to climate change by Chepang households in the rural Mid-Hills of Nepal. Reg Environ Chang 13:437-447. https:// doi.org/10.1007/s10113-012-0359-5

Rachik H (2007) Nomads: but how? In: Gertel J, Breuer I (eds) Pastoral Morocco - globalizing scapes of mobility and insecurity. Reichert, Wiesbaden, pp 211-252

Schilling J, Freier KP, Hertig E, Scheffran J (2012) Climate change, vulnerability and adaptation in North Africa with focus on Morocco. Agric Ecosyst Environ 156:12-26

Taruvinga A, Visser M, Zhou L (2016) Determinants of rural farmers' adoption of climate change adaptation strategies: evidence from the Amathole District Municipality, Eastern Cape Province, South Africa. Int J Environ Sci Dev 7(9):687-692. https://doi.org/10.18178/ijesd.2016.7.9.863

Tesfahunegn GB, Mekonen K, Tekle A (2016) Farmers' perception on causes, indicators and determinants of climate change in northern Ethiopia: implication for developing adaptation strategies. Appl Geogr 73:1-12

Tiwari KR, Rayamajhi S, Pokharel RK, Balla MK (2014) Determinants of the climate change adaptation in rural farming in Nepal Himalaya. Int J Multidiscip Curr Res 2:234-240

Yila JO, Resurreccion BP (2013) Determinants of smallholder farmers' adaptation strategies to climate change in the semi-arid Nguru Local Government Area, Northeastern Nigeria. Manag Environ Q Int J 24(3):341-364

Yohe G, Malone E, Brenkert A et al (2006) Global distributions of vulnerability to climate change. Integr Assess 6:35-44

Open Access This chapter is licensed under the terms of the Creative Commons Attribution 4.0 International License (http://creativecommons.org/licenses/by/4.0/), which permits use, sharing, adaptation, distribution and reproduction in any medium or format, as long as you give appropriate credit to the original author(s) and the source, provide a link to the Creative Commons license and indicate if changes were made.

The images or other third party material in this chapter are included in the chapter's Creative Commons license, unless indicated otherwise in a credit line to the material. If material is not included in the chapter's Creative Commons license and your intended use is not permitted by statutory regulation or exceeds the permitted use, you will need to obtain permission directly from the copyright holder.

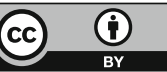

